\title{
Analyses of Deposited and Granted Patents at Federal University of Ceara in Brazil
}

\author{
Lídia Audrey Rocha Valadas', Lídia Rodrigues Queiroz', Mary Anne Medeiros Bandeira', Rosueti Diógenes de Oliveira Filho', Érika Sabóia

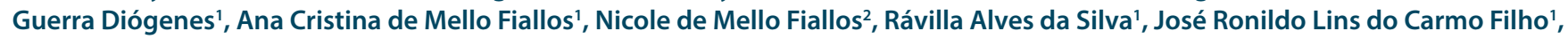 \\ Camila Costa Dias' ${ }^{1}$ Emerson Dias Ponte ${ }^{1}$, Carlos Eduardo Lima Fernandes ${ }^{3}$, Allana Bezerra Capistrano ${ }^{1}$, Paulo Arthur Mendonça Bruno ${ }^{4}$, \\ João Hildo de Carvalho Furtado Júnior ${ }^{1}$
}

'School of Pharmacy, Dentistry and Nursing, Federal University of Ceara, Fortaleza-CE-BRAZIL.

${ }^{2}$ School of Dentistry, Estadual University of Rio de Janeiro, Rio de Janeiro-RJ-BRAZIL.

${ }^{3}$ School of Medicine. Federal University of Paraíba, João Pessoa-PB- BRAZIL.

\begin{abstract}
Background: Investments in patents are more and more widespread at the capitalism, because all the system working is related to the innovation and the technological and scientific advance, in which the industries and universities have a fundamental rule. When those researches generate a product, this can be patented, being deposited initially on an intellectual property bank and thus the inventor and his group will have exclusively the product rights by a time period that varies according to the country legislation. Objective: Due do the increasing interest from the general universities in innovation, the objective was to conduct a prospective study about patents deposited by the Federal University of Ceara (UFC) at the National Institute of Industrial Property (INPI) that is the organ responsible by the Brazil intellectual property. To do so, were selected all the deposited patents by the university till nowadays. Experimental Section: Were found deposits of 123 patents, in which 43 hadn't achieved the publication process and 3 expired. Conclusion: After the analyses of the Federal
\end{abstract}

University of Ceara patents, is concluded that the majority is related to the products classes with medical, dental and hygiene finalities and that the interest of the refereed university in relation to the intellectual property protection is still small, being interesting a greater divulgation on the subject in the university.

Key words: Universities, Intellectual Property I, Patents, Technology, Prospective Study.

Correspondence :

Lídia Audrey Rocha Valadas,

Carlos Vasconcelos Street, 1330, Fortaleza-Ce, BRAZIL.

Tel: +55 85997361292

Email: lidiavaladas@gmail.com

DOI: 10.5530/jyp.2017.9.61

\section{INTRODUCTION}

Investments in patents are more and more widespread at the capitalism, because all the system working is related to innovation and the technological and scientific advance. To this advance is essential the existence of the intellectual property rights through the patents' protection. Being that, the right to the intellectual property has an important rule on a country economic development. ${ }^{1}$

Nowadays is grand the investment made by universities and industries in researches for innovation and technology. Prospective studies in intellectual property banks are important to increase market competitiveness and thus generate new products in the various research areas. When those researchers generate a product, this can be patented, being deposited initially in an intellectual property bank and thus the inventor and his group or a company will have exclusively the product rights for a time period, and this varies according to the country legislation. To something be patented is necessary to have the following characteristics: Innovation, technology and commercialization possibility. ${ }^{2,3}$

The institutions or intellectual property banks are the responsible for the patents deposits and granting. Each country has a responsible bank and the legislation varies according to the nation, among these are against National Institute of Induntrial Property (Brazil), Canadian Intellectual Property Office (Canada), German Patent and Trademark Office (Germany), Japanese Patent Office (Japan), UK Patent Office (United Kingdom), United States Patent and Trademark Office (United States), World Intellectual Property Organization (Europe). Prospective studies in intellectual property banks are important to keep the market competition and thus to generate new products on many researches areas. Despite of the important information source, those studies are few utilized and many times unknown on the academic world. ${ }^{3,4}$

With each passing day is increased the universities relation to the country economic development and companies, many of them having already an internal structure that transmits the scientific knowledge products to the enterprise ambient. It is in this context that the intellectual property has gained more and more notoriety and has increasing the governmental policies that helps the university in this process with the enterprises. ${ }^{5,6}$

To begin a patent process in a public university, the inventor and his group, through a report, make the deposit request that can be accepted or not by the university that will be the deposit holder. In the case of the university shows interest, all the documentation is given by the sector on the National Institute of Industrial Property- INPI. ${ }^{3}$

The universities have a really important rule on the technology and the country innovation system, a system composed by all the institution that somehow is contributing to the country technological development and innovation.?

Due to the increasing interest of the general universities by the innovation, was aimed to conduct a prospective study about the patents deposited by the Federal University of Ceara at the INPI. 


\section{EXPERIMENTAL SECTION}

It is about a prospective study, conducted from August to November 2016, in which were conducted researches about patents deposited by the Federal University of Ceara (UFC) at the Industrial Property National Institute (INPI), that is the responsible organ by the intellectual property in Brazil.

To do so, were selected all the patents deposited by the UFC until 2016. Shortly thereafter, the findings were placed in table forms on the Microsoft Excel 2013 software and graphics.

\section{Prospective study}

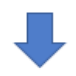

\section{Searching on the INPI patents bank}

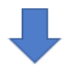

Patents at the Federal University of Ceara name

\section{RESULTS AND DISCUSSION}

Were found deposits of 123 patents, from this total, 46 hadn't achieved the publication process and 3 lapsed patents. Probably for loss of deadlines or were not in the criteria that INPI required. On graphic 1 it can be observed the quantity of product deposits at the Federal University of Ceara and those request situations. From 1985, data of the first deposit by the university till 2015, were made 123 (100\%) deposits, where 77 $(62.6 \%)$ were published by the National Institute of Industrial PropertyINPI, $3(2.4 \%)$ are from expired patents, that are the patents that missed the deadline and the remaining $46(35 \%)$ are waiting for publication.

Despite of being an institution officially founded in the 50's and internationally recognized by its publications and development in scientific research, the UFC presents a low number of deposit of patents. In Brazil, the number of deposits by brazilian universities overpasses the companies at the INPI, being the University of Campinas the institution with more deposits number. ${ }^{8}$

At the INPI there are 7743 patents deposits made by universities, 4513 are from Federal Universities of the country (graphic 2), among those only 123 (2.72\%) belongs to the UFC (INPI, 2015). According to Oliveira

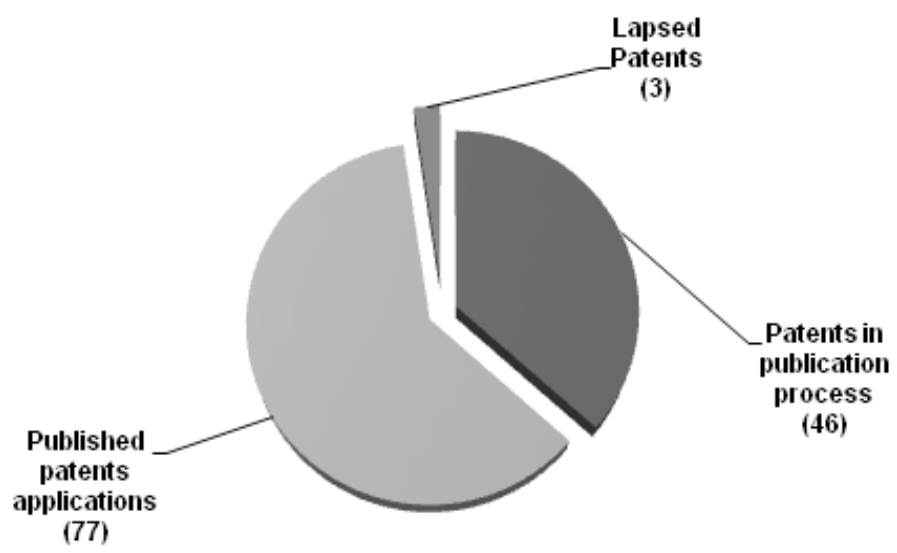

Graphic 1: Relation between the patents situations in the Federal University of Ceara.

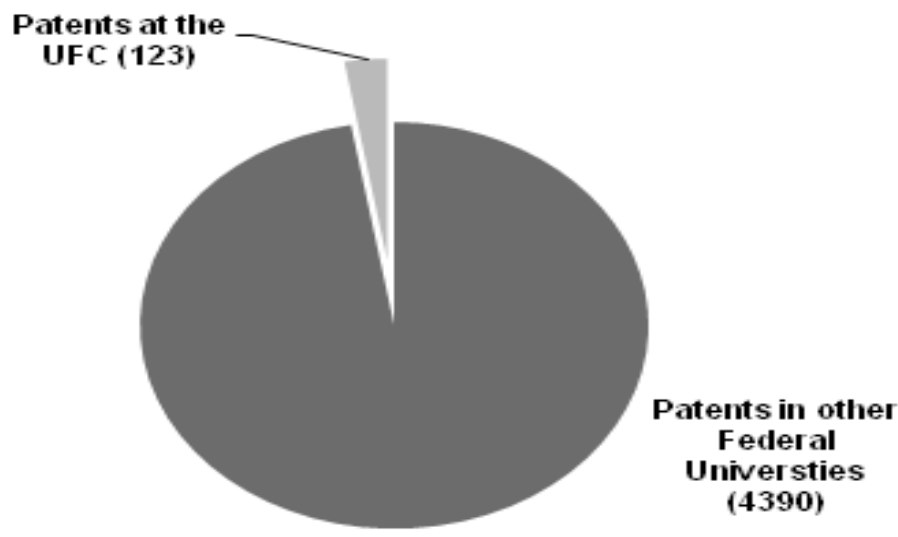

Graphic 2: Relation between the patents of all federal universities in Brazil and the Federal University of Ceara.

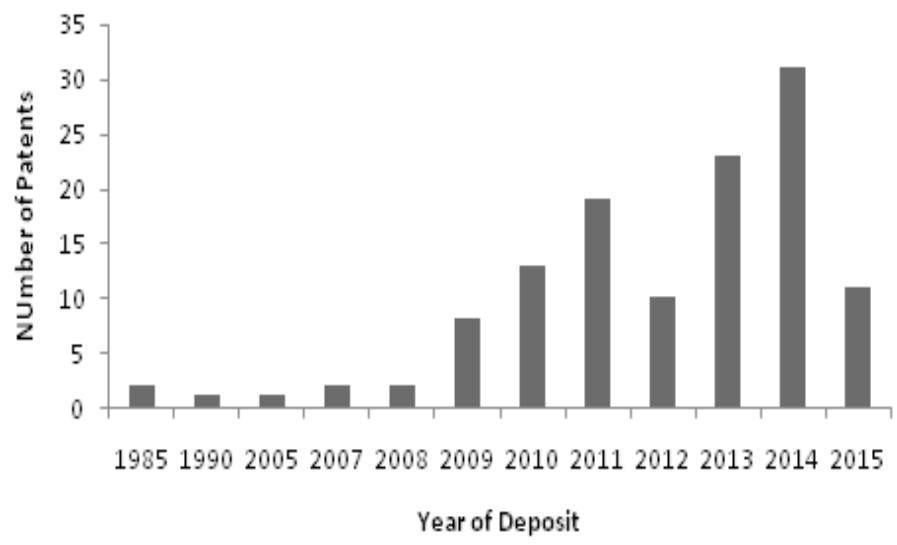

Graphic 3: Relation between the patents deposits over the years by the Ceará Federal University.

(2014), the lack of interest from some researchers in patent their invention is given by the priority to publish articles, by the lack of knowledge of the proceedings to make the patents deposit and the lack of public guidelines at the universities. ${ }^{9}$

Probably the explanation to that is that the researchers prefer to publish articles in scientific journals, seen that there are many exigencies by the post-graduation programs and the promotion organs, although this kind of publication is so important and should be much considered as. The lack of knowledge about the deposit process maybe also contributes to this low number.

On graphic 3 it can be observed the distribution of the Federal University of Ceara deposits over the years at the INPI. Despite of the quantity be modest, it is understood a significant increasing of the deposit number between the years 2010 and 2015 .

Although not being a new theme, the discussion in relation to the intellectual property at the universities is a recent theme and few discussed in Brazil, but what is receiving more and more notoriety and being treated in many institutions, increasing thus each day its importance and influence on the country economy. It is known that the Law number 9.729, from May $14^{\text {th }}, 1996$, which is about the patent legislation, was a mark about the theme in Brazil. Another mark was the Law number 10.973, from December $2^{\text {nd }}, 2004$, treating about incentive measures to the innovation and the scientific and technological research, authorization thereby that the Union, the states, cities and promotion agencies, stimulates the interaction among companies and entities turned to the scientific and technological research. ${ }^{6,8-10}$ 


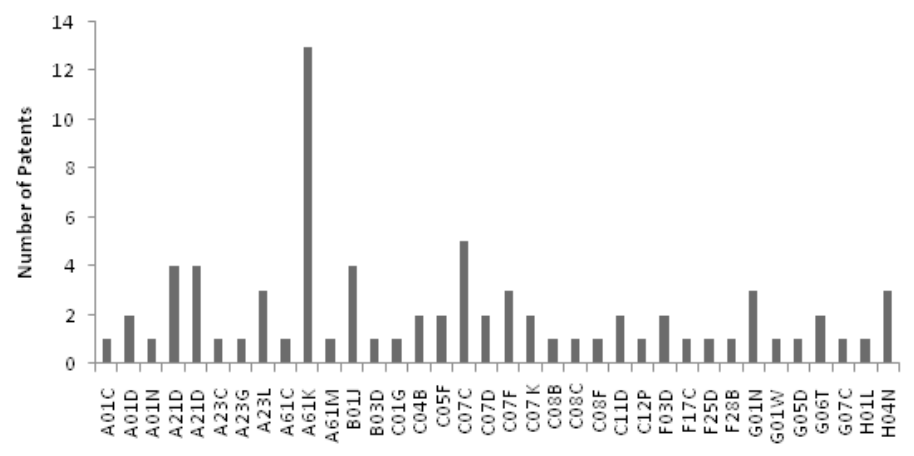

Patents Classification

Graphic 4: Patents classification and quantity of deposits

After the innovation law creation in 2004, the science and technology institutes were obligated to create the technological innovation centers to be the responsible by the deposits of professors research to the INPI and the mediators with the companies, beginning thus an innovation policy in the university and formalizing the technological innovation management in the universities, in a way to surge a strategic policy to the country ${ }^{11,12,13}$

On January 2016, the pilot project of the Patent Prosecution Highway (PPH), which provides for cooperation between patent offices in Brazil and the United States, entered into force. This project aims to improve the efficiency of the processing of patent applications, consequently a significant reduction in the term of the examination. The agreement that guaranteed the execution of this pilot project was signed between the National Institute of Industrial Property.

(INPI) and the United States Patent and Trademark Office (USPTO) during the Brazil-United States Trade Dialogue (MDIC-DoC) held in November 2015, in Brasilia, Brazil. ${ }^{3}$

To facilitate the researches, the patents have an international classification system since 1971 that distribute them per codes, being this known as IPC - International Patent Classification. According to this classification, the products are in technological areas of the types $\mathrm{A}$ to $\mathrm{H}$, that have its own division, denominated as classes, that in its turn are subdivided in subclasses (Table 1).

This classification aims to establish an efficient and easy to access searching tool, thus amplifying the product divulgation. ${ }^{13}$

On Graphic 4 we can be seen the patents classification in the types/classes and the quantity. On Graphic 5, can be understood that the most conducted deposits by the UFC are the types A (26\%), referring to human necessities products. The types with fewer deposits (4.0\%) were the $B$, referring to processes and transports and $\mathrm{F}$, referring to the mechanical engineering, illumination, heating, weapon and explosion. The type D about textile and papers and the type $\mathrm{E}$ about the fixed constructions haven't any deposit and 37\% of the deposits are still in secrecy.

The globalization stimulated the development, not only scientific but also technological at the universities. It shall be emphasized that the patents aren't only resource sources or financial advantages and those study institutions, they also are important to give notoriety to the scientific

Table 1: Classes of patents deposited by the Federal University of Ceara and its quantity, according to the International Patents Classification - IPC and its descriptions.

\begin{tabular}{|c|c|c|}
\hline Type & Classes & Description \\
\hline \multirow[t]{4}{*}{ A - Human necessities } & A01 & Agriculture \\
\hline & $\mathrm{A} 21, \mathrm{~A} 22, \mathrm{~A} 23, \mathrm{~A} 24$ & Food products; Tobacco \\
\hline & $\mathrm{A} 41, \mathrm{~A} 42, \mathrm{~A} 43, \mathrm{~A} 44, \mathrm{~A} 45, \mathrm{~A} 46, \mathrm{~A} 47$ & Personal or domestic items \\
\hline & A61, A62, A63, A99 & Health, rescue or leisure \\
\hline \multirow[t]{5}{*}{ B-Processing operations - Transport - } & В01, В02, В03, В04, В05, В06, В07, В08, В09 & Separation, mixture \\
\hline & $\mathrm{B} 21, \mathrm{~B} 22, \mathrm{~B} 23, \mathrm{~B} 24, \mathrm{~B} 25, \mathrm{~B} 26, \mathrm{~B} 27, \mathrm{~B} 28, \mathrm{~B} 29, \mathrm{~B} 30, \mathrm{~B} 31, \mathrm{~B} 32, \mathrm{~B} 33$ & Conformation \\
\hline & B41, B42, B43, B44 & Impression \\
\hline & $\mathrm{B} 60$, B61, B62, B63, B64, B65, B66, B67, B68 & Transport \\
\hline & B81, B82, B99 & Microstructure technology nanotechnology \\
\hline \multirow[t]{3}{*}{ C- Chemistry; Metallurgical } & $\begin{array}{c}\mathrm{C} 01, \mathrm{C} 02, \mathrm{C} 03, \mathrm{C} 04, \mathrm{C} 05, \mathrm{C} 06, \mathrm{C} 07, \mathrm{C} 08, \mathrm{C} 09, \mathrm{C} 10, \mathrm{C} 11, \mathrm{C} 12, \mathrm{C} 13 \text {, } \\
\mathrm{C} 14\end{array}$ & Chemistry \\
\hline & $\mathrm{C} 21, \mathrm{C} 22, \mathrm{C} 23, \mathrm{C} 25, \mathrm{C} 30$ & Metallurgical \\
\hline & C40, C99 & Combinatory technology \\
\hline \multirow[t]{2}{*}{ D- Textile; Paper } & D01, D02, D03, D04, D05, D06, D07 & $\begin{array}{c}\text { Textile or flexible materials not included in } \\
\text { other place }\end{array}$ \\
\hline & D21, D99 & Paper \\
\hline \multirow[t]{2}{*}{ E-Fixed constructions } & E01, E02, E03, E04, E05, E06 & Edification \\
\hline & E21, E99 & Ground drilling; mining \\
\hline \multirow{3}{*}{$\begin{array}{l}\text { F-Mechanical engineering; Illumination; } \\
\text { Heating; Weapons; Explosion }\end{array}$} & F01, F02, F03, F04 & Motors or pumps \\
\hline & F15, F16, F17 & General engineering \\
\hline & F21, F22, F23, F24, F25, F26, F27, F28 & Illumination; Heating \\
\hline \multirow[t]{3}{*}{ G- Physics } & F41, F42, F99 & Weapons; Explosion \\
\hline & G01, G02,G03,G04, G05, G06, G07, G08, G09, G10, G11, G12 & Instruments \\
\hline & G21, G99 & \\
\hline \multirow[t]{2}{*}{ H- Electricity } & H01, H02, H03, H04, H05, H99 & Nucleonic \\
\hline & & - \\
\hline
\end{tabular}




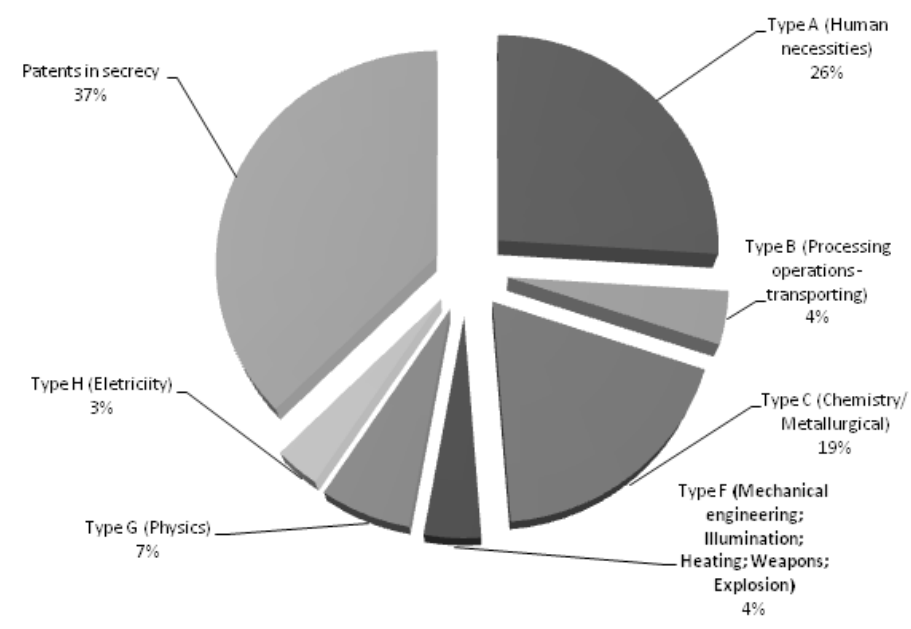

Graphic 5: Relation between the classification and distribution of patent deposits at the Federal University of Ceara.

research and to the professors /researchers, as well as articles published in scientific journals, being also an innovation indicator. The lack of interest of some researchers in patenting their inventions is given by the priority in publishing articles, by the lack of knowledge in the procedures for filing patents and the lack of public guidelines in universities. ${ }^{10}$

Besides being resource source to universities, the patents are important to give notoriety to the scientific research and to the professors/researchers, as well to the scientific articles.

\section{CONCLUSION}

After the analyses of patents from the Federal University of Ceara at INPI, it is conclude that the majority is related to the product class with medical, dental and hygiene finalities.

It can be understood that in the referred university the interest in relation to the intellectual protection is still small, being interesting a larger divulgation about the subject in the university. Administrative actions should be taken to encourage and guide researchers to make more patent deposits.

\section{ACKNOWLEDGEMENT}

The authors are thankful to Federal University of Ceará for providing necessary facilities to carry out the work.

\section{CONFLICT OF INTEREST}

No conflict of interest are declared.

\section{ABBREVIATION USED}

UFC: Federal University of Ceará; INPI: National Institute of Industrial Property; UK: United Kingdom; PPH: Patent Prosecutin Highway; USPTO: United States Patent and Trademark Office; IPC: International Patent Classification.

\section{REFERENCES}

1. Lima JAA. Digressões sobre Propriedade Intelectual como agente de desenvolvimento, Inovação e Estratégia. Fórum HSM de Estratégia. 2006;10(93):45-55.

2. Ferreira AA, Guimarães ER, Contador JC. Patente como instrumento competitivo e como fonte de informação tecnológica. Gest Prod. 2009;16(2):209-21. https://doi.org/10.1590/S0104-530X2009000200005.

3. INPI. Instituto Nacional de Propriedade Industrial. Disponível em: <http:// www. inpi.gov.br>, Acesso em: 07 nov. 2016.

4. Jannuzzi AHL, Souza CG. Patentes de invenção e artigos científicos: especificidades e similitudes. RBPG. 2009;5(9):103-25.

5. Amadei JRP, Amadei AL, Torkomian V. As patentes nas universidades: análise dos depósitos das universidades públicas paulistas. Ciência da Informação. 2009;38(2):9-18. https://doi.org/10.1590/S0100-19652009000200001.

6. Mueller SPM, Perucchi V. Universidades e a produção de patentes: tópicos de interesse para o estudioso da informação tecnológica. Perspectivas em Ciência da Informação. 2014;19(2):15-36. https://doi.org/10.1590/1981-5344/1828.

7. Cohen WM, Nelson RR, Walsh JP. Links and Impacts: The Influence of Public Research on Industrial R\&D. Management Science. 2002;48(1):1-23. https:// doi.org/10.1287/mnsc.48.1.1.14273

8. Dagnino RD, Silva RB. As patentes das universidades públicas. Economia \& Tecnologia. 2009;18(5):169-72. https://doi.org/10.5380/ret.v5i3.27147.

9. Oliveira RM, Velho LMLS. Patentes acadêmicas no Brasil: uma análise sobre as universidades públicas paulistas e seus inventores. Parc Estrat. 2009; 14(29):173-200.

10. Haase H, Araújo EC, Dias J. Inovações vistas pelas patentes: exigências frente às novas funções das universidades. Revista Brasileira de Inovação. 2005;4(2):12-22.

11. Assunção E. O sistema de patentes e as universidades brasileiras nos anos 90 . Rio de Janeiro: INPI, 2000.

12. Castro BS, Souza GCO. O papel dos Núcleos de Inovação Tecnológica (NITs) nas universidades brasileiras. Liinc em Revista. 2012;8(1):125-40. https://doi. org/10.18617/liinc.v8i1.465.

13. Machado BAS, Cruz LS, Nunes SB, Guez MAU, Padilha FF. Estudo prospectivo da própolis e tecnologias correlatadas sob o enfoque em documentos de patentes depositados no Brasil. Revista GEINTEC. 2012;2(3):221-35. https://doi. org/10.7198/S2237-0722201200030003. 